\title{
Share Centralization, Investor Sentiment and Firm Performance
}

\author{
Chia-Hsin Cheng \\ Business School, Yulin Normal University, Yulin, China
}

Email address:

ccheng686@gmail.com

\section{To cite this article:}

Chia-Hsin Cheng. Share Centralization, Investor Sentiment and Firm Performance. International Journal of Business and Economics Research. Vol. 8, No. 3, 2019, pp. 78-84. doi: 10.11648/j.ijber.20190803.11

Received: March 16, 2019; Accepted: May 6, 2019; Published: May 29, 2019

\begin{abstract}
The purpose of this paper is to identify how internal corporate governance and external investor sentiment impacts the operating performance of the firm. The corporate governance mechanism affects the firm's operating activities, and transfers its results to outside investors by public financial reports. Since the universal uninformed investors could only identify the firm's net income instead of accrual earnings, this paper reflects the "visible" accounting number to represent investors' received information differently from literatures. Sampling the Taiwanese listed companies from 2007 to 2014, I demonstrate variable definition, build regression models and examine them by full sample analysis and by grouping analysis. The results show three points contributed to professional and business field. The first is that both the higher investor sentiment and the larger shareholding percentage of the board are relevant to reported performance. In addition, because the investor sentiment is encouraged by firm's net income, the managers should devote to better earnings for borrowing equity capital when the firm's debt ratio is high. Finally, only in the situation that the enterprise faces low investor sentiment and little shareholding of the board is the shareholding percentage negative relationship to the operating performance. It infers that instead of informing the firm's prospect to the outside investors, the board might hold on its share right inside of the firm.
\end{abstract}

Keywords: Corporate Governance, Investor Sentiment, Operating Performance, Share Concentration

\section{Introduction}

Since the Enron incident occurred in 2001, corporate governance has played the important role in mechanisms of firms' business operations, financial information disclosure, and accounting fraud prevention. Literatures have mainly focused on the regulation of accounting information disclosure [1], the supervision in enterprise fraud [2], the business operations involved by the board [3], and the financial information content by media coverage [4]. Conveniently, Scholars have regarded corporate governance as an internal control mechanism. The high level of corporate governance reduced in the information asymmetry in a company and might enhance a positive effect on stock returns. Conversely, the insufficiency of corporate governance might confuse investors' perception and weaken long-term stock return.

In recent years, the rise of finance and behavioral accounting has encouraged scholars to study the abnormal returns in the stock market. Overreaction of investor sentiment, such as the overreaction prior to a corporate event and the under-reaction after the event window, highlights how stock returns can be deviated from expectations. In addition, managers manipulate the information disclosure practices to profit from abnormal stock returns, which cause loss from uninformed investors.

Since corporate governance is one of the important mechanisms to use to monitor the firm's internal activities, it keeps the quality of the financial report that serves as the main communication channel to the public [5]. To specify this effect of Chinese-based enterprises that growth fast in the world recently, the purpose of this paper aims to identify the operating performance of the Chinese-based firm operated by the internal governance under various levels of the external investor sentiment.

Most literatures identify earnings management as the quality of information in financial reports. However, regarding the information quality of long-term earnings and that of operational performance, only is accounting earnings readable rather than discretionary accruals by uninformed investors [6]. Thus this paper is straight-forward to sample the 
earnings in Taiwanese listed companies from 2007 to 2014, and investigates the relationships among corporate governance, investor sentiment, and the performance disclosed in financial reports. The empirical results show that good corporate governance conveniently improves the firm's operating performance. However, when in the poor share-holding in the board coordinated with low level of investor sentiment, the improvement in share concentration might hurt the operating performance. These results can be distinguished from those studies in well-developed countries to serve as one of the characteristics in Chinese managerial field.

\section{Literature Review}

The literature is presented in three parts. It comprises studies related to corporate governance, investor sentiment, and earnings performance.

\subsection{Corporate Governance}

The Corporate Governance Index was well developed by Gompers and Metrick [7], who demonstrated that companies with well-developed corporate governance keep high shareholder rights to achieve great profits. Thereafter, the relationship between the effect of corporate governance and investors' reaction became a popular research topic. Concerning the internal governance, Cheng [8] identified the level of power centralization in managers affects the results of company operations. Iliev, Lins, Miller, and Roth [9] suggested that the shareholder right is ones of the effective mechanisms for implementing corporate governance. For the external environment, Giroud and Mueller [10] specified that the effect for monitoring corporate governance decreases when the industrial competition is going down. Consequently, managers in monopolistic firms apply risk aversion that might lose favorable investment opportunities. This finding confirmed the association between the external environment and the internal corporate governance. Arora [11] suggested that future studies on corporate governance could focus on emerging markets in developing countries, and thus meet the urgent requirement of these countries to develop a comprehensive corporate governance mechanism.

The corporate governance in Chinese-based companies has received marked attention in resent literatures. Bai, Liu, Lu, Song, and Zhang [12] claimed that investors are willing to pay a considerable premium to well-governance firms. In addition, they might require the corporate supervision to ensure the sustainable business operations. Zheng [2] reported that when companies are under financial distress, major shareholders might display the high tendency to participate in illegal funding allocation. In this condition, the board members could only execute limited effect on corporate governance. Yin, Huang, and Xiao [13] demonstrated that the high shareholding concentration improves corporate governance, and the ownership diversification could cause severe corporate governance problems. Finally, Huyghebaert and Wang [14] discovered that the Chinese ownership control could improve the enterprise value, which made academic contribution to the Chinese accounting and financial research.

In recent years, more literatures turned to the attributes of good corporate governance and their effect on the firm's operating performance. Cai, Zeng, Lee and Ozkan [15] found that the Chinese enterprises with group affiliation kept less cash holdings and thus improved the free-cash-flow problem of agency costs. Srivastav and Hagendorff [16] highlighted the need for shareholders, creditors, and the taxpayer in the internal governance mechanisms. Lin, Liu and Noronha [17] more advanced that good corporate governance practices could motivate firm managers to disclosure informative earnings management. Cheng, Lee and Shevlin [18] demonstrated that the internal governance is stronger for firms where key subordinate executives' contribution is higher. In addition, Agrawal and Cooper [19] oppositely showed that bad governance mechanisms would follow accounting scandals. Garcia-Sanchez and Garcia-Meca [20] further argued that governance mechanisms are effective to cover inefficient investment decisions. At the last, Horstmeyer [21] studied internal monitoring as the internal governance concerns. Colli and Colpan [22] identified academic research on corporate governance in business groups has become the new developing field.

\subsection{Investor Sentiment}

Baker and Wurgler [23] discussed on how investor sentiment affects company stock returns. In subsequence, Ali and Gurun [24] noted that the stock price of the small firm is more prone to the influence of investor sentiment than that in the large enterprise because the market participants are mostly composed with individual investors for the small firm. Hwang [25] identified that investors and enterprises in various cultural backgrounds could generate comprehensive empirical results. Therefore, Baker, Wurgler, and Yuan [26] distinguished investor sentiments into global and local sentiments according to regional characteristics, and concluded that the flow of global investor sentiment also affects the stock returns of listed firms in specific regions. Chou, Huang, and Yang [27] reported that the trading volume of individual stocks does not only represent the characteristics of investor sentiment, but also exhibits the arbitrage risk of the stock market. Mclean and Zhao [28] suggested that investor sentiment tends to be low during economic recession, which increase enterprises' external financing costs and thus influence the future investment of enterprises. Even in Chinese empirical investigation, Shin [29] demonstrated that macro-economic shock made the asymmetric pricing effect mirrored the investor reactions. Chu and Qiu [30] also found that the price limit hits could be the proxies of the Chinese investor sentiment, but might not substitute to other proxies mentioned in literatures completely. Recently, Huang, Jin and Chen [31] argued that the firm could borrow cheap loans when the investor sentiment is high, which reminded managers to keep good relationship to the outside investors. Sun, Zhao, Wang and Cho [32] demonstrated when the investor sentiment is low, 
managers would adjust their approach to corporate social responsibility disclosure. In addition, Wu, Liu, Han and Yin [33] found that the irrational factors from the investor sentiment could affect analysts' forecast bias. These findings stress the outside investors might express their "emotion" through the stock market, which change the decisions from other stakeholders. Finally, Chen, Chou and Lin [34] concluded that in the high-sentiment period, managers are more motivated to conduct seasoned equity offerings. These SEO firms were thus experienced less severe short-run price drops around the issuance.

\subsection{Earnings Performance}

The motivation and implications of enterprise earnings performance have been investigated and discussed for years. Healy and Palepu [35] summarized the theories and empirical results in previous studies to conclude that the manipulation of earnings management is possibly caused by firm managers who intend to inform the operational statuses and future prospects of the firms by reporting firm performance and corporate governance. Although well-developed corporate governance is generally assumed to lead to favorable earnings performance, a variety of corporate governance indices are available. Ali, Chen, and Radhakrishnan [36] identified that ownership structure affects the quality of earnings reports, thus explaining why family enterprises can report relatively favorable earnings. Larcker, Richardson, and Tuna [3] applied a principal component analysis to collectively analyze 14 indices of corporate governance that influence earnings performance. Richardson, Tuma, and Wysocki [37] further conducted a comprehensive literature review on the relationship between financial report performance and stock price. Later, MujtabaMian and Sankaraguruswamy [38] indicated that the mispricing of earnings is one of the reasons for fluctuations in investor sentiment. By reviewing the empirical studies, Han, He, Pan, and Shi [39] finally concluded the operating performance of the Chinese-based enterprises has developed innovative research questions due to their rising global influence and ongoing regulatory reforms.

For the present, thinking about earnings performance has been developed in four fields. The first is the informativeness of earnings. Since the informed investors are sensitive to the earnings report [40], firms with historically larger earnings have higher stock returns [41]. The fundamental analysis of the firm could still provide useful insights for lenders [42]. In addition, the macro-economic factors and the industry profitability could also affect the firm's earnings [43, 44]. The second is the effect of earnings management. Numerous literatures reported evidence about how managers choose accounting reports to drive investors' figures of the firm [45]. Henry and Peytcheva [46] also identified that investors could distinguish between good and poor firm performance when the top management makes emphases in the financial statements. However, DeBoskey, Luo and Zhou [47] found the tone used in the earnings announcement is positively associated with CEO tenure and duality. The third is to discover the lankness between the corporate governance and the earnings performance. When the firm is well executed its governance mechanism and social responsibility, the earnings per share could represent the enterprise's fair value and the dividend payout is satisfied $[48,49]$. On the other hand, while the firm with busy board connections might hurt its operating performance [50]. At the last, the earnings qualitative protection from accounting principles is discussed. Caskey and Laux [51] discussed that the conservative accounting is desirable because it allows the board to better oversee the firm's investment decisions. Accounting comparability is also effective for the evaluation in CEO compensation and for the explanation about future earnings [52, 53].

From the perspective of managers, the main purpose of disclosing firm performance in financial reports is to effectively present the managerial results to investors. Long-term stability of earnings reduces the manipulation effect in earnings reports. Moreover, the uninformed investors of the public could not have enough abilities to calculate and analyze the level of arbitrary accruals embedded in the financial reports. Therefore, this study applies operating returns as an information indicator of the long-term performance of firms to investigate whether public investors understand the disclosure information in financial reports, and thereby determinates the role of corporate governance in the Chinese-based firms conditional on the level of investor sentiment.

\section{Research Methods}

\subsection{Data Source and Processing}

This study uses Performance, Governance, and Sentiment as the proxy variables of firm operating performance, corporate governance, and investor sentiment, respectively. The data are retrieved from the database of the 2007-2014 Taiwanese Economics Journal Database (TEJ). In the original 19,121 entries of data, flawed entries such as those with incomplete information and those for which the absolute value of operating returns exceeded $100 \%$ have been removed. A total of 18,783 empirical data entries are retained.

\subsection{Empirical Model}

This paper aims to investigate the co-effect of corporate governance and investor sentiment on the operating performance of Chinese-based companies. Based on several studies mentioned below, I construct the empirical model as below:

$$
\begin{aligned}
& \text { Performance }_{\mathrm{i}, \mathrm{t}+1}=\beta_{0}+\beta_{1} * \text { Governance }_{\mathrm{i}, \mathrm{t}}+\beta_{2} * \text { Sentiment }_{\mathrm{i}, \mathrm{t}} \\
& \quad+\beta_{3} * \text { Debt }_{\mathrm{i}, \mathrm{t}}+\beta_{4} * \text { Market }_{\mathrm{t}}+{\text { year_effect }+\varepsilon_{\mathrm{i}, \mathrm{t}}}
\end{aligned}
$$

In equation (1), I footnote that the i-th form's operating performance in year $\mathrm{t}+1$ is driven by its internal governance, outside investor sentiment and other of the variables in year $t$. Distinguished from that Cornett, Marcus, and Tehranian [54], and Wang and $\mathrm{Ni}$ [55] have examined corporate governance's influence on earnings management. I introduce the operating return ratio as the financial report performance, and propose that it is the most convenient for managers to 
inform outside investors the firm's future prospects. Because the uninformed investors could not have enough abilities to analyze the information from accruals management, they might just make investing decisions from reported earnings disclosure from financial statements.

Since Larcker, Richardson, and Tuna [3] proposed that not all of the indices are suitable for assessing corporate governance, this paper refers Lin, Chih, Cheng, and Wei [56] to apply the percentage of shares held by board members as the proxy of the internal corporate governance. The shareholding percentage of the board exhibits higher sensitivity than do other variables, such as the scale of the board or the number of independent board members. Moreover, applying this variable could avoid policy noise such like the requirements to the number of independent board members. In addition, in accordance with the examination by Chou, Huang, and Yang [27], I employ the natural algorithm of the mean of single-day trading volume of specific stocks as the proxy variable for investor sentiment At last, the corporate debt ratio in the single quarter and the natural algorithm of the price-weighted index of the Taiwanese stock market are set as control variables in this paper. To mitigate the influence of extreme sample values, this paper made the natural logarithms of excessive variable values to avoid statistical bias. Also, I consider the year effect to improve the empirical explanation.

\section{Empirical Results}

The importance of corporate governance in Taiwan has been promoted for years, and thus the distribution of the shareholding percentage of the board could introduce in its policy achievement. Table 1 details the descriptive statistics of the sample as below:

Table 1. Descriptive statistics of the model variables.

\begin{tabular}{|c|c|c|c|c|c|c|c|c|c|c|}
\hline & Mean & Median & SD & $\operatorname{Max}$ & Min & Q1 & Q3 & Skewness & Kurtosis & Obser-vations \\
\hline Performance & 0.01 & 0.01 & 0.03 & 0.63 & -1.59 & 0.01 & 0.02 & -9.75 & 480.75 & 18,783 \\
\hline Governance & 18.85 & 14.97 & 13.03 & 87.83 & 0.12 & 9.43 & 24.58 & 1.57 & 3.07 & 18,783 \\
\hline Sentiment & 6.98 & 7.00 & 1.74 & 11.94 & -0.41 & 5.81 & 8.19 & -0.18 & 0.10 & 18,783 \\
\hline Debt & 45.21 & 44.60 & 18.93 & 98.55 & 0.99 & 31.43 & 56.83 & 0.39 & 0.01 & 18,783 \\
\hline Market & 8.94 & 8.98 & 0.16 & 9.16 & 8.43 & 8.90 & 9.06 & -1.57 & 2.32 & 18,783 \\
\hline
\end{tabular}

Table 1 indicates that over $75 \%$ of the board's shareholding percentage is below $50 \%$. The result reveals that low share-holding of the board could cover minority investors' protection. The trading volume assessed for the investor sentiment is relatively well-distributed when compared with that of the shareholding percentage.

This finding indicates that the investor sentiment is unaffected by the board's operating rights. Table 2 presents the correlations among the investigated variables.

Table 2. The correlation coefficients among the variables.

\begin{tabular}{|c|c|c|c|c|c|}
\hline & Performance & Governance & Sentiment & Debt & Market \\
\hline Performance & 1 & - & - & - & - \\
\hline Governance & $0.0377^{* * *}$ & 1 & - & - & - \\
\hline Sentiment & $0.0296^{* * *}$ & $0.0369^{* * *}$ & 1 & - & - \\
\hline Market & $0.1093^{* * *}$ & $0.0069^{* * *}$ & $0.0063^{* * *}$ & $-0.0255^{* * *}$ & 1 \\
\hline
\end{tabular}

$*, * *$, and $* * *$ indicate significant difference from zero at the $10,5,1$ percent levels, respectively.

I first examine the single effect of corporate governance and investor sentiment on operating performance. The examination determines whether the corporate governance and investor sentiment would significantly affect the firm's operation or not. The results show that investors prefer to the well-performance firm by large trading volume, and that the high share concentration of the board improves the firm's operating performance. That is, even though the share-decentralization is promoted by the market regulation, the Chinese-based firm might make better operation by higher share concentration of the board. This managerial characteristic is quite different from the West literatures. Thus, I input the debt ratio and the market weight-average index to control the co-effect by the corporate governance and the investor sentiment. The debt decision is considered to affect the firm's performance, and the stock market condition also represents the outside environment of the firm. I emphasize these two variables and make the empirical results in Table 3.
Table 3. Regression analysis of corporate governance and investor sentiment.

\begin{tabular}{lll}
\hline & $\mathbf{( 1 )}$ & $\mathbf{( 2 )}$ \\
\hline Intercept & $-0.0035^{* * *}$ & $-0.1923^{* * *}$ \\
& $(-2.87)$ & $(-11.53)$ \\
Governance & $0.0001^{* * *}$ & $0.0001^{* * *}$ \\
& $(6.24)$ & $(5.98)$ \\
Sentiment & $0.0006^{* * *}$ & $0.0010^{* * *}$ \\
& $(4.73)$ & $(7.57)$ \\
Debt & & $-0.0003^{* * *}$ \\
& & $(-23.68)$ \\
Market & & $0.0226^{* * *}$ \\
& & $(12.31)$ \\
Year Effect & Yes & Yes \\
Adj. R2 & 0.0099 & 0.0464 \\
Observations & 18,783 & 18,783 \\
\hline
\end{tabular}

The values within parentheses are $\mathrm{t}$ statistics. $* * *$, and $* * *$ indicate significant difference from zero at the $10,5,1$ percent levels, respectively. 
The results in Table 3 reveals that corporate governance and investor sentiment still make positive effects on firm operating performance comprehensively. Moreover, the external market environment is significantly correlated with the firm's operating performance. However, the debt ratio is negatively correlated with operating performance, inferred that the Chinese-based firms might prefer to raise their capital by issuing equity rather than debt. This finding could also explain why the national equity involved in the
Chinese-based firm is so important.

My empirical results confirm the efficiency of a sole majority shareholder. That is, the higher the share-holding of the board is, the more favorable the operating performance becomes. Since managers might meet the outside investors' perception, I divide my samples into four groups based on the cross-level between the internal corporate governance and the external investor sentiment. Table 4 represents the results:

Table 4. Regression analysis of grouping samples on firm operating performance.

\begin{tabular}{|c|c|c|c|c|}
\hline & $\begin{array}{l}\text { High Governance } \\
\text { High Sentiment }\end{array}$ & $\begin{array}{l}\text { High Governance } \\
\text { Low Sentiment }\end{array}$ & $\begin{array}{l}\text { Low Governance } \\
\text { Low Sentiment }\end{array}$ & $\begin{array}{l}\text { Low Governance } \\
\text { High Sentiment }\end{array}$ \\
\hline intercept & $\begin{array}{l}-0.2151^{* * *} \\
(-7.69)\end{array}$ & $\begin{array}{l}-0.1423^{* * *} \\
(-4.65)\end{array}$ & $\begin{array}{l}-0.1116^{* * *} \\
(-2.64)\end{array}$ & $\begin{array}{l}-0.2678^{* * *} \\
(-8.07)\end{array}$ \\
\hline Sentiment & $\begin{array}{l}0.0006^{* *} \\
(2.35)\end{array}$ & $\begin{array}{l}0.0026^{* * *} \\
(7.58)\end{array}$ & $\begin{array}{l}0.0008^{* * *} \\
(2.67)\end{array}$ & $\begin{array}{l}0.0002^{* *} \\
(2.54)\end{array}$ \\
\hline Market & $\begin{array}{l}0.0263^{* * *} \\
(8.67)\end{array}$ & $\begin{array}{l}0.0163^{* * *} \\
(4.84)\end{array}$ & $\begin{array}{l}0.0136^{* * *} \\
(2.95)\end{array}$ & $\begin{array}{l}0.0318^{* * *} \\
(8.80)\end{array}$ \\
\hline Year Effect & Yes & Yes & Yes & Yes \\
\hline Adj. R2 & 0.0473 & 0.0786 & 0.0270 & 0.0525 \\
\hline Observations & 4,696 & 4,696 & 4,696 & 4,695 \\
\hline
\end{tabular}

The values within parentheses are $\mathrm{t}$ statistics. $*^{* *}$, and $* * *$ indicate significant difference from zero at the $10,5,1$ percent levels, respectively.

The empirical results for all groups in Table 4 exhibit significant consistency regarding the effects of corporate governance, investor sentiment, and other controlled variables. The higher operating performance is correlated to the more optimal investor response. In addition, a significant inverse relationship between the board's share concentration and the firm's operating performance is only observed when in the low level of both the external investor sentiment and the internal share-holding of the board. It infers that when in the poor condition of investor sentiment and power decentralization, the effort for the Chinese-based board's share concentration might hurt the firm's operating results. Conversely, the high share concentration of managers creates positive effects on firm operating performance. This inference provides evidence for the fact that Chinese-based family firms make better performance rather than others in general.

\section{Conclusion}

The purpose of this paper is to investigate the co-effect of corporate governance and investor sentiment on the operating performance of the Chinese-based firm. Sampled by the listed companies in TEJ from 2007 to 2014, the empirical results show three main findings for managers and investors. First, increasing the internal share centralization and encouraging the external investor sentiment could positively affect the firm's operating performance alternatively. That is, the higher investor sentiment, the better reported performance. And the larger shareholding of the board, the bigger operating results. Second, since the outside investors make decision from the firm's financial statements, managers should improve the financial results first for borrowing cheap equities. At the last, by grouping regression analysis I find that the better performance of the firm could be dominated by the stimulation of the outside investor sentiment, whether the inside shareholding increases or not. The firm's performance is worse only in the situation that the enterprise faces low investor sentiment outside and little shareholding of the board inside.

Different from the literature respected the effect of supervision by corporate governance; I denote the operating contribution of the high share concentration in the Chinese-based board. In addition, attributed to the small scale of Taiwanese environment, the financial results are also sensitive to the factors from the stock market. Thus for regulation making, my finding identifies the importance of information disclosure in Chinese-based financial reports. At last, my conclusion encourages the share concentration in the board, and highlights the importance for uniformed investor recognition.

\section{References}

[1] Heflin, F. and C. Hsu (2008). The impact of the SEC's regulation of non-GAAP disclosures. Journal of Accounting and Economics 46, 349-365.

[2] Zheng, K. J, D. J. Lin and F. D. Zhang (2013). The effectiveness of corporate governance on the firm's fraud and big shareholder's bankruptcy. World of Management 2013 (5), 157-168.

[3] Larcker, David F, Scott A. Richardson and I'rem Tuna (2007). Corporate governance, accounting outcomes, and organizational performance. The Accounting Review 82 (4), 963-1008. 
[4] Tetlock, P. C. (2007). Giving content to investor sentiment: the role of media in the stock market. Journal of Finance 62 (3), $1139-1168$

[5] Davis A. K. and J. M. Piger (2012). Beyond the numbers: measuring the information content of earnings press release language. Contemporary Accounting Research 29 (3), 845-868.

[6] Dechowa, Patricia, Weili Geb and Catherine Schrand (2010). Understanding earnings quality: a review of the proxies, their determinants and their consequences. Journal of Accounting and Economics 50, 344-401.

[7] Gompers, Paul and Andrew Metrick (2003). Corporate governance ad equity prices. The Quarterly Journal of Economics 118 (1), 107-155.

[8] Cheng, S. (2008). Board size and the variability of corporate performance. Journal of Financial Economics 87, 157-176.

[9] Iliev, Peter, Karl V. Lins, Darius P. Miller and Lukas Roth (2011). Shareholder voting and corporate governance around the world. Review of Financial Studies 28 (8), 2167-2202.

[10] Giroud, Xavier and Holger M. Mueller (2010). Does corporate governance matter in competitive industries?. Journal of Financial Economics 95, 312-331.

[11] Akshita Arora, "Literature review assessing the relationship between corporate governance and firm performance". Compendium of Research Papers of National Conference on Managing tomorrow: Issues and Challenges by D. Y Patil Institute of Management Studies, vol 2, pp. 394-424, 2015.

[12] Bai, C. E, Q Liu, Z. Lu, M. Song and J. X. Zhang (2005). An empirical study on Chinese listed firms' corporate governance. Economic Research 2, 81-91.

[13] Yin, Z. J, J. H. Huang and M. Xiao (2015). Is the single big holder bad for corporate governance: an evidence-based on shareholding model and two types of governance cost. Academic Journal of GuangDong University of Finance and Economics 6 (143), 60-72.

[14] Huyghebaert, Nancy and L. H. Wang (2019). Value creation and value distribution in Chinese listed firms: the role of ownership structure, board characteristics, and control. European Journal of Finance 25 (6), 465-488.

[15] Cai, W, C. Zeng, E. Lee and N. Ozkan (2016). Do business groups affect corporate cash holdings? Evidence from a transition economy. China Journal of Accounting Research 9 (1), 1-24.

[16] Srivastav, A. and J. Hagendorff (2016). Corporate Governance and Bank Risk-taking. Corporate Governance-An International Review 24 (3), 334-345.

[17] Lin, Z, M. Liu and C. Noronha (2016). The Impact of Corporate Governance on Informative Earnings Management in the Chinese Market. Abacus-A Journal of Accounting Finance and Business Studies 52 (3), 568-609.

[18] Cheng, Q, J. Lee and T. Shevlin (2016). Internal Governance and Real Earnings Management. Accounting Review 91(4), 1051-1085.

[19] Agrawal, A. and T. Cooper (2017), Corporate Governance Consequences of Accounting Scandals: Evidence from Top Management, CFO and Auditor Turnover. Quarterly Journal of Finance 7 (1). DOI: 10.1142/S2010139216500142.
[20] Garcia-Sanchez, IM. and E. Garcia-Meca (2018). Do talented managers invest more efficiently? The moderating role of corporate governance mechanisms. Corporate Governance-An International Review 26 (4), 238-254.

[21] Horstmeyer, D. (2019). Beyond Independence: CEO Influence and the Internal Operations of the Board. Quarterly Journal of Finance 9 (2). DOI: 10.1142/S201013921950006X.

[22] Colli, A. and A. M. Colpan (2016). Business Groups and Corporate Governance: Review, Synthesis, and Extension. Corporate Governance-An International Review 24 (3), 274-302.

[23] Baker, Malcolm and Jeffrey Wurgler (2006). Investor sentiment and the cross section of stock returns. Journal of Finance 61 (4), 1645-1680.

[24] Ali, Ashiq and Umit G. Gurun (2009). Investor sentiment, accruals anomaly, and accruals management. Journal of Accounting, Auditing and Finance 24 (3), 415-431.

[25] Hwang, Byoung-Hyoun (2011). Country-specific sentiment and security prices. Journal of Financial Economics 100 (2), 382-401.

[26] Baker, Malcolm, Jeffrey Wurgler and Yu Yuan (2012). Global, local, and contagious investor sentiment. Journal of Financial Economics 104 (2), 272-287.

[27] Chou, P. H, T. Y. Huang and H. J. Yang (2013). Arbitrage risk and the turnover anomaly. Journal of Banking and Finance 37, $4172-4182$.

[28] Mclean, R. and David, M. Zhao (2014). The business cycle, investor sentiment, and costly external finance. Journal of Finance 69 (3), 1377-1409.

[29] Shin, Jae Eun (2019). Asymmetric Investor Reaction around Earnings Benchmark under Economic Uncertainty. Asia-Pacific Journal of Financial Studies 48 (1), 98-122.

[30] Chu, Xiaojun, J. Y. Qiu (2019). Forecasting Volatility with Price Limit Hits-Evidence from Chinese Stock Market. Emerging Markets Finance and Trade 55 (5), 1034-1050.

[31] Huang, H, G. Jin and J. Chen (2016). Investor sentiment, property nature and corporate investment efficiency: based on the mediation mechanism in credit financing. China Finance Review International 6 (1), 56-76.

[32] Sun, W, C. Zhao, Y. Wang and C. H. Cho (2018). Corporate social responsibility disclosure and catering to investor sentiment in China. Management Decision 56 (9), 1917-1935.

[33] Wu, Y, T. Liu, L. Han and L. Yin (2018). Optimistic bias of analysts' earnings forecasts: Does investor sentiment matter in China?. Pacific-Basin Finance Journal 49, 147-163.

[34] Chen, Y. W, R. K. Chou, C. B. Lin (2019). Investor sentiment, SEO market timing, and stock price performance. Journal of Empirical Finance 51, 28-43.

[35] Healy, P. and K. Palepu (2001). Information asymmetry, corporate disclosure, and the capital markets: a review of the empirical disclosure literature. Journal of Accounting and Economics 31, 405-440.

[36] Ali, A, Ty Chen and S. Radhakrishnan (2007). Corporate disclosures by family firms. Journal of Accounting and Economics 44, 238-286. 
[37] Richardson, Scott A, I'rem Tuna and Peter Wysocki (2010). Accounting anomalies and fundamental analysis: a review of recent research advances. Journal of Accounting and Economics 50, 410-454.

[38] Mujtabamian, G. and S. Sankaraguruswamy (2012). Investor sentiment and stock market response to earnings news. The Accounting Review 87 (4), 1357-1384.

[39] Han, Jianlei, Jing He, Zheyao Pan and Jing Shi (2018). Twenty Years of Accounting and Finance Research on the Chinese Capital Market. Abacus-A Journal of Accounting Finance and Business Studies 54 (4), 576-599.

[40] Noda, Akihiro (2018). Auditor choice as a commitment device. Journal of Financial Reporting And Accounting 16 (3), 374-394.

[41] Chang, T. Y, S. M. Hartzmark, D. H. Solomon and E. F. Soltes (2017). Being Surprised by the Unsurprising: Earnings Seasonality and Stock Returns. Review of Financial Studies 30 (1), 281-323.

[42] Cheng, Q, Y. J. Cho and H. Yang (2018). Finanmant reporting changes and the internal information environment: Evidence from SFAS 142. Review of Accounting Studies 23 (1), 347-383.

[43] Joslin, Scott and Yaniv Konchitchki (2018). Interest rate volatility, the yield curve, and the macro-economy. Journal of Financial Economics 128 (2), 344-362.

[44] Jackson, Andrew B, M. A. Plumlee and B. R. Rountree (2018). Decomposing the market, industry, and firm components of profitability: implications for forecasts of profitability. Review of Accounting Studies 23 (3), 1071-1095.

[45] Alsharairi, M, R. Dixon and R. Al-Hamadeen (2017). Event-specific earnings management: additional evidence from US M\&A pre-and post-SOX. Journal of Financial Reporting And Accounting 15 (1), 78-98.

[46] Henry, Elaine and Marietta Peytcheva (2018). Earnings-Announcement Narrative and Investor Judgment. Accounting Horizons 32 (3), 123-143.
[47] DeBoskey, D. G, Y. Luo and L. Zhou (2019). CEO power, board oversight, and earnings announcement tone. Review of Quantitative Finance And Accounting 52 (2), 657-680.

[48] Tshipa, J, L. Brummer, H. Wolmarans and E. Du Toit (2018). The impact of flexible corporate governance disclosures on value relevance: Empirical evidence from South Africa. Corporate Governance-The International Journal of Business in Society 18 (3), 369-385.

[49] Cheung, A, M. Hu and J. Schwiebert (2018). Corporate social responsibility and dividend policy. Accounting and Finance 58 (3), 787-816.

[50] Brown, A. B, J. Dai and E. Zur (2019). Too Busy or Well-Connected? Evidence from a Shock to Multiple Directorships. Accounting Review 94 (2), 83-104.

[51] Caskey, J. and V. Laux (2017). Corporate Governance, Accounting Conservatism, and Manipulation. Management Science 63 (2), 424-437.

[52] Lobo, G. J, M. Neel, A. Rhodes (2018). Accounting comparability and relative performance evaluation in CEO compensation. Review of Accounting Studies 23 (3), 1137-1176.

[53] Choi, JH, S. Choi, L. A. Myers and D. Ziebart (2019). Financial Statement Comparability and the Informativeness of Stock Prices about Future Earnings. Contemporary Accounting Research 36 (1), 389-417.

[54] Cornett, M. M, A. J. Marcus and H. Tehranian (2008). Corporate governance and pay-for-performance: the impact of earnings management. Journal of Financial Economics 87, 357-373.

[55] Wang, C. R. and Ni J. (2012). Share structure, board characteristics and earnings management. Academic Journal of Anhui University 2012 (1), 141-149.

[56] Lin, Y. E, H. H. Chih, C. H. Cheng and L. R. Wei (2015). The impact of industrial structure on capital expenditure: evidence from Taiwan. Cross-Strait Financial Journal 3 (1), 47-66. 